\title{
Disrupting Technology Disrupting Law
}

Kieran Tranter ${ }^{\#}$

\begin{abstract}
This Commentary disrupts technology disrupting law. It suggests that "disruption" is increasingly becoming a framework when lawyers write about technology. It is argued that this disruption frame is problematic. It is problematic because it reveals a surprising presentism lacking both a sense of the past and a coherent vision of the future. Further, this presentism produces an essential contradiction. There is a vision of hyper-change; a tsunami of disruption needing law; nevertheless the forms of modern law seemingly endure. This opens to what is fundamentally worrying about the disruption frame. In its affirmation of modern law as able to manage disruption, the disruption frame obscures the significant transformation of law occurring in the digital. Technology is disrupting law in much more significant ways than is being considered by the disruption frame.
\end{abstract}

Key words: Technology, Disruption, Modern Law, Digital Law, Automated Vehicles

\section{Disruption}

In recent years the word “disruption” has increasingly been used to frame technology's impact on law. ${ }^{1}$ In particular lawyers have identified specific “disruptive technologies” as

\footnotetext{
\# Associate Professor, Law Futures Centre, Griffith Law School, Griffith University. I would like to thank Lyndal Sleep, John Flood, Samuli Haataja, Mark Brady and Morgan Broman whose contributions and conversations developed these arguments. All errors and omissions are my own.
} 
rendering existing laws and legal activity problematic, necessitating clarification and reform.

Located in this framework the emergence of big health data is said to create challenges for

health law. ${ }^{2}$ The development of legal artificial intelligences (AI) and related technologies

are seen to threaten the future of the legal profession. ${ }^{3}$ 3D printing, it is claimed, interrupts

established intellectual property and controlled items regimes. ${ }^{4}$ Similarly, the appearance of ride-sharing services requires the rethinking of transport regulation and consumer law ${ }^{5}$, while civil drones require changes to aerospace and privacy law. ${ }^{6}$ The common thread between these disruptive technologies has been the “digital.” Indeed, “digital disruption” has become embedded in the semiosphere as a catchphrase for a generation concerned with how

\footnotetext{
${ }^{1}$ N. Katyal, 'Disruptive Technologies and the Law', Georgetown Law Journal, 102 (2014), H.L. Vogel, 'Disruptive Technologies and Disruptive Thinking ', Michigan State Law Review [2005], R.H. Brescia, 'What We Know and Need to Know about Disruptive Innovation’, South Carolina Law Review 67 (2016).

${ }^{2}$ F. Khan, 'The Uberization of Healthcare: The Forthcoming Legal Storm over Mobile Health Technology's Impact on the Medical Profession', Health Matrix: Journal of Law-Medicine 26 (2016), M.G. Bloche, 'The Emergent Logic of Health Law’, Southern California Law Review 82 (2009), K. Garrety, I. McLoughlin, R. Wilson, G. Zelle and M. Martin, 'National Electronic Health Records and the Digital Disruption of Moral Orders', Social Science and Medicine 101 (2014), R. Best and G. Khushf, 'The Social Conditions for Nanomedicine: Disruption, Systems, and Lock-in', Journal of Law, Medicine and Ethics 34 (2006).

${ }^{3}$ R.A. Abadin, 'A Hard Conversation: Now What', Florida Bar Journal 90 (2016), P. Lippe, 'What We Know and Need to Know about Watson, Esq’, South Carolina Law Review 67 (2016), R.G. Pearce and J.O. McGinnis, 'The Great Disruption: How Machine Intelligence will Transform the Role of Lawyers in the Delivery of Legal Services', Fordham Law Review 82 (2014), B. Simpson, 'Algorithms or Advocacy: Does the Legal Profession Have a Future in a Digital World', Information and Communications Technology Law, 25 (2016), D.M. Katz, 'Quantitative Legal Prediction - Or - How I Learned to Stop Worrying and Start Preparing for the Data-Driven Future of the Legal Services Industry’, Emory Law Journal 62 (2013), D.R. Mountain, 'Could New Technologies Cause Great Law Firms to Fail’, Syracuse Law Review, 52 (2002).

${ }^{4}$ D.R. Desai, 'The New Steam: On Digitization, Decentralization, and Disruption', Hastings Law Journal 65 (2014), C.J. Craig, 'Technological Neutrality: Recalibrating Copyright in the Information Age’, Theoretical Inquiries in Law 17 (2016), A. Thierer and A. Marcus, 'Guns, Limbs, and Toys: What Future for 3D Printing ', Minnesota Journal of Law, Science and Technology 17 (2016), R. Stephens, 'Rolling Your Own: 3D Printed Drugs and the Controlled Substances Act', Georgetown Journal of Law and Public Policy 14 (2016).

${ }^{5}$ A. Pfeffer-Gillett, 'When Disruption Collides with Accountability: Holding Ridesharing Companies Liable for Acts of Their Drivers', California Law Review 104 (2016), R.E. Elliott, 'Sharing App or Regulation Hack(ney): Defining Uber Technologies, Inc’, Journal of Corporation Law 41 (2016), H.A. Posen, 'Ridesharing in the Sharing Economy: Should Regulators Impose Uber Regulations on Uber’, Iowa Law Review 101 (2015), K. Barglind, 'Innovation, Technology, and Transportation: The Need to Address On-Demand Ridesharing and Modernize Outdated Taxi Regulations in the US', Wisconsin International Law Journal 33 (2015), S.P. King, 'Sharing Economy: What Challenges for Competition Law?', Journal of European Competition Law and Practice 6 (2015), C. Holloway, 'Uber Unsettled: How Existing Taxicab Regulations Fail to address Transportation Network Companies and Why Local Regulators Should Embrace Uber, Lyft, and Comparable Innovators', Wake Forest Journal of Business and Intellectual Property Law 16 (2015).

${ }^{6}$ M.N. Widener, 'Local Regulating of Drone Activity in Lower Airspace', Boston University Journal of Science and Technology Law 22 (2016), T.D. Lovett, 'Ruling the Skies or Drowning in Rules: A Look at the FAA's Sluggish Progress in Developing Rules and Forces that might be Shaping the Future of Drone Use in the United States', Barry Law Review 21 (2016), C. Schlag, 'The New Privacy Battle: How the Expanding Use of Drones Continues to Erode Our Concept of Privacy and Privacy Rights’, Pittsburgh Journal of Technology Law and Policy, 13 (2013), R. Clarke, 'Appropriate Regulatory Responses to the Drone Epidemic', Computer Law and Security Review 32 (2016).
} 
information and communication technologies are seemingly changing social, political and economic relations. ${ }^{7}$

The idea that technology “disrupts” has its origins in Harvard Business School’s Clayton Christensen's 1997 The Innovator's Dilemma. ${ }^{8}$ In that book Christensen looks at how firms develop products and how decisions to incrementally innovate and improve existing products for existing clients has led to the decline of specific firms. His insight is that established firms fail to develop radically new products for new customers; while new products tend to be developed outside of established market players. He suggests that by the time the new product is gaining market share it is too late in the cycle for the established firm to respond. Within Christensen's initial context the idea of “disruptive technology” was not tied to the digital; with only one of his case studies on disk-drives manufacturing and innovation over the 1970 s-1990s relating to information and communication technologies. ${ }^{9}$ Further, Christensen’s original use of “technologies”” was misleading. In his later work he prefers the term "disruptive innovation", confessing that his focus is on the business model that surrounds the technology rather than the technology itself. ${ }^{10}$ His example for this change in emphasis is the motor vehicle. He claims that the elite vehicles produced in the pioneering era of motoring were not disruptive of horse and buggy related transport industries until Henry Ford, the Model T and the business model of mass production emerged in $1908 .^{11}$

It can be seen that Christensen gave birth to a buzzword that has gone on to flourish in the semiosphere, including in the ways lawyers talk about technology and law. Christensen's

\footnotetext{
${ }^{7}$ O. Lobel, 'The Law of the Platform ', Minnesota Law Review 101 (2016), E. Schmidt and J. Cohen, 'The Digital Disruption - Connectivity and the Diffusion of Power’, Foreign Affairs, 89 (2010), S. Lindgren, New Noise: A Cultural Sociology of Digital Disruption (New York, Peter Lang Publishing Group, 2013).

${ }^{8}$ C.M. Christensen, The Innovator's Dilemma: When New Technologies Cause Great Firms to Fail (Boston, Harvard Business Review Press, 1997).

9 Op. cit., 3-28.

${ }^{10}$ C.M, Christensen and M.E. Raynor, The Innovator's Solution: Creating and Sustaining Successful Growth (Boston, Harvard Business Press, 2003), p.32, J.M. Utterback and H.J. Acee, 'Disruptive Technologies: An Expanded View’, International Journal of Innovation Management 9 (2005).

${ }^{11}$ Christensen and Raynor, Innovator's Solution, p. 49.
} 
critics have suggested that underpinning “disruption”, and explaining its proliferation in the semiosphere, is anxiety and crisis: "Our era has disruption, which despite its futurism, is atavistic. It's a theory of history founded on a profound anxiety about financial collapse, an apocalyptic fear of global devastation.”12 In Christensen’s work the history of innovation and the rise and fall of firms was something to learn from, mistakes that Harvard MBA alumni running established firms should avoid when making investment decisions. ${ }^{13}$ Disruption was to be managed, and best avoided so the profits, and the status quo, could continue to flow.

This means that the innocuous suggestion that technology disrupts law freights several problematic assumptions into thinking about law and technology. It is an overstimulated optic that in seeing too much change, fails to perceive and assess the actual transformations occurring. The consequence of disruption's baggage is impoverished thinking on law and technology.

Hence, in what follows I disrupt technology disrupting law. The first section identifies the theoretical poverty of the disruption frame for thinking law and technology; that it has a surprising presentism lacking both a sense of the past and a coherent vision of the future. I do this through an examination of the legal scholarship that responds to the disruption of automated road vehicles. In the second section it is argued that this presentism produces an essential contradiction. There is a vision of hyper-change; a tsunami of disruption needing law. Yet as will be seen through revisiting the law and automated road vehicle scholarship, law, the forms of modern law endure; a rock in a sea of disruption. The third section argues that disruption's presentism renders opaque the significant transformation of law occurring in the digital; transformations to the material substrate of what has been known as law.

\footnotetext{
12 J. Lepore, 'The Disruption Machine’, The New Yorker 23 (2014), p. 32.

${ }^{13}$ M. Wessel and C.M. Christensen, 'Surviving Disruption', Harvard Business Review 90 (2012).
} 


\section{The Presentism of Technology Disrupting Law}

It would be difficult to charge Christensen with presentism. His innovation texts are case studies about various firms during the twentieth century from which he crafts his theory of disruptive innovation and how it can be managed. However, this historicism is not evident when lawyers talk of technology disrupting law; as can be identified in the recent legal scholarship that has arisen in response to automated road vehicles.

Automated road vehicles are described in law journals as disruptive. ${ }^{14}$ This disruption tends to have two distinct focuses. The first is a more strictly Christensen related focus - automated vehicles it is suggested have the potential to disrupted established firms and services in the motor vehicle sector. Automated vehicles might herald the rise of innovated firms that disrupt established manufacturers, service providers, and taxi and hire-car providers. ${ }^{15}$ This disruption might extend to public transport and maybe disrupt some of the car focus-ness of urban planning. ${ }^{16}$ This is speculation as to the winners and losers in the survival of the fittest within a capitalist ecosystem of self-driving cars. This disruption is not marked by the presentism of the second focus. There is often some allusion that automated road vehicles might involve a repeat of the story Christensen told of Ford and the disruption of the horse and buggy industries. ${ }^{17}$

\footnotetext{
${ }^{14}$ A. Thierer and R. Hagemann, 'Removing Roadblocks to Intelligent Vehicles and Driverless Cars', Wake Forest Journal of Law and Policy 5 (2015), pp. 340, 348, J. Boeglin, 'The Costs of Self-Driving Cars: Reconciling Freedom and Privacy with Tort Liability in Autonomous Vehicle Regulation', Yale Journal of Law and Technology, 17 (2015), p. 180, S. Peck, L. Fatehi, F. Douma and A. Lari, 'The SDVs Are Coming - An Examination of Minnesota Laws in Preparation for Self-Driving Vehicles', Minnesota Journal of Law, Science and Technology 16 (2015), p.848.

${ }^{15}$ D.J. Glancy, 'Autonomous and Automated and Connected Cars - Oh My: First Generation Autonomous Cars in the Legal Ecosystem', Minnesota Journal of Law, Science and Technology 16 (2015), p. 626.

16 Op. cit., pp. 670-673, B.W. Smith, 'Managing Autonomous Transportation', Santa Clara Law Review 52 (2012).

${ }^{17}$ Thierer and Hagemann, Removing Roadblocks, p. 350. I have some concerns with this condensed historical description of the emergence of mainstream motor vehicles with Ford and the disruption of horse and buggy firms. In the pioneer period of motoring in Australia there was less disruption and much more adoption and
} 
The second focus of disruption has less history; it is that automated road vehicles disrupt law. The suggestion is succulent and anxiety ridden. It is that automated road vehicles displace the foundation of how law has reckoned, regulated and ruled the motor vehicle for the past 100 years, by interrupting the nexus between vehicle and owner/driver. ${ }^{18}$ Law of the car - traffic law, motor vehicle liability law, criminal laws relating to the motor vehicle, licensing of drivers and vehicle registration and registries - it is claimed had a simple ontology. Vehicles were things, property that is owned by a competent legal person; while it was the competent legal person's doing in cars that was the addressee of law's dictates. The law of the car involved telling the owner/driver what can be done and what cannot be done with motor vehicles.

The disruption of automated vehicles to law - where self-driving hardware and software pilots the vehicle while the human occupants entertain themselves doing nondriving activities - is self-evident. The nexus between vehicle and the traditionally responsible legal person is broken. At this point in the technology disrupting law narrative rhetorical questions flourish. If the vehicle speeds who gets the ticket? ${ }^{19}$ Is an occupant or manufacturer liable if there is an accident ${ }^{20}$ Who can have access to the vehicle's data? ${ }^{21}$

\footnotetext{
transformation by horse and buggy (and bicycle) firms to the 'horse-less carriage.' Many of the early car manufacturers were saddlers or buggy makers and often the first generation of garages began as blacksmiths or bicycle shops. The car was not disruptive in a total way but innovative firms that diversified from their existing product line to make, sell and service the new machines thrived. See K. Tranter, "The History of the HasteWagons': The Motor Car Act 1909 (Vic), Emergent Technology and the Call for Law', Melbourne University Law Review 29 (2005).

${ }^{18}$ B.W. Smith, ‘Automated Vehicles Are Probably Legal in the United States ‘, Texas A\&M Law Review 1 (2014).

${ }^{19}$ K. Tranter, 'The Challenge of Autonomous Motor Vehicles and Queensland Road and Criminal Laws', Queensland University of Technology Law Review 16 (2016), p. 64.

${ }^{20}$ Thierer and Hagemann, Removing Roadblocks, p 360, J. Thomas, 'Putting Programmers in the Driver's Seat: State Tort Systems Applied to Autonomous Automobiles’, University of Detroit Mercy Law Review 93 (2016), p. 566, Boeglin, Costs of Self-Driving Cars, p. 199, C. Brock, 'Where We’re Going, We Don’t Need Drivers: The Legal Issues and Liability Implications of Automated Vehicle Technology’, UMKC Law Review 83 (2015), p. 772; A.R. Swanson, 'Somebody Grab the Wheel: State Autonomous Vehicle Legislation and the Road to a National Regime’, Marquette Law Review 97 (2014), p. 1118, O. Ravid, 'Don’t Sue Me, I Was Just Lawfully Texting \& Drunk When My Autonomous Car Crashing into You’, Southwestern Law Review 44 (2014), pp. 1791-80, G.E. Marchant and R.A. Lindor,, 'The Coming Collision between Autonomous Vehicles and the Liability System’, Santa Clara Law Review 52 (2012), p.1326, A.P. Garza, ‘"Look Ma, No Hands!": Wrinkles and Wrecks in the Age of Autonomous Vehicles', New England Law Review 46 (2012), p. 589.
} 
Does an occupant of an automated vehicle need to be licensed driver? ${ }^{22}$ Can an intoxicated occupant travel in an automated vehicle ${ }^{23}$ What can be seen within these questions is an anxiety of the present. The existing law of the car is presented as a static, ahistorical whole. ${ }^{24}$ Detailed and successful, much like Christensen’s established firms, but vulnerable at its very core.

Rhetorical questions like these are a symptom of presentism. ${ }^{25}$ The existing is given and the "what if" presupposes an uncertain and challenging future. What is absent from the automated road vehicle and law scholarship is a sense that the law of the car has always been in flux. It did not just appear instantaneously and fully-formed with Carl Benz but has been continuously reformed through legislation, litigation, standards and public advocacy. Road rules are continuously being updated; litigation is continuous refining liability rules; standards on safety, emissions and fuel consumption change. ${ }^{26}$ It has a history of change, of adaption and development. It has responded to successive disruptions such as the emergence of mass mechanized personal transport, the need to compensate for road trauma, congestion, pollution, and consumer rights.

While the past of car law is obscured by the focus on disruption, its future is as well. Thinking law and technology invokes a speculative jurisdiction; envisioning of how

\footnotetext{
${ }^{21}$ Thierer and Hagemann, Removing Roadblocks p. 386, U. Bose, 'The Black Box Solution to Autonomous Liability’, Washington University Law Review, 92 (2015), p. 1326.

${ }^{22}$ H. Surden and M.A. Williams, 'Technological Opacity, Predictability, and Self-Driving Cars', Cardozo Law Review 38 (2016), p. 136.

${ }^{23}$ J.K. Gurney, 'Driving into the Unknown: Examining the Crossroads of Criminal Law and Autonomous Vehicles', Wake Forest Journal of Law and Policy 5 (2015), p. 393, K.L. Hanna, 'Old Laws, New Tricks: Drunk Driving and Autonomous Vehicles', Jurimetrics 55 (2015). F. Douma and S.A. Palodichuk, "'But Officer, it wasn’t my Fault...the Car Did it!": Criminal Liability Issues Created by Autonomous Vehicles’, Santa Clara Law Review 52 (2012), p. 1163.

${ }^{24}$ An exception is K. Graham, 'Of Frightened Horses and Autonomous Vehicles: Tort Law and its Assimilation of Innovations', Santa Clara Law Review 52 (2012).

${ }^{25}$ E. Black, Rhetorical Questions: Studies of Public Discourse (Chicago, University of Chicago Press, 1992), J.S. Nelson, Tropes of Politics: Science, Theory, Rhetoric, Action (Madison, Wisconsin, University of Wisconsin Press, 1998).

${ }^{26}$ K. Guzik, 'Taking Hold of the Wheel: Automobility, Social Order, and the Law in Mexico’s Public Registry of Vehicles (REPUVE)', Law and Society Review 47 (2013). S.S. Lochlann Jain, Injury: The Politics of Product Design and Safety Law in the United States (Princeton, New Jersey, Princeton University Press, 2006).
} 
technologies would lead to change. ${ }^{27}$ However, the focus of disruption on a specific technology - automation of vehicles - limits the vista of the future. Historians of technology rarely identify linear change from a single technology. Indeed, Christensen in his revised term "disruptive innovations" seems to acknowledge this; that observable change happens when a combination of hard technological things and soft technological processes and practices coincide. Technologies tend to come in clusters, bound up with changing social practices and economic relations. ${ }^{28}$ For the motor vehicle and the law of the car, automation is only one vector of change; with electrification and collectivization also transforming the car-system. $^{29}$ The future of the car will involve automation but it also will involve the transition to electric vehicles and the decline of the oil distribution network, as well as increasing numbers of consumers moving away from a property model of car ownership to a contract model of purchasing automobile transport when required. ${ }^{30}$ To get a better vision of the future of the motor vehicle, and the needs of future car law, a patient cartography of how these vectors are remaking the car and automobility is required. This is not what the disruption frame allows. The myopic focus on the disruption of automation renders the future partial and out of focus. The disruption frame does not presuppose a past; nor does it really see the future. It is anxiously stuck in the present; concerned with what the future holds yet ignorant of its past.

This presentism of technology disrupting law leads directly to an essential contradiction; an emphasis on the need for legal change yet a continual affirmation of law as it has been known; a desire to manage disruption using the forms and tools of modern law.

\footnotetext{
${ }^{27}$ K. Tranter, 'The Speculative Jurisdiction: The Science Fictionality of Law and Technology ', Griffith Law Review 20 (2011).

${ }^{28}$ A. Feenberg, Questioning Technology (London, Routledge, 1999).

${ }^{29}$ K.G. Rees, 'Accelerate, Reverse, or Find the Off Ramp? Future Automobility in the Fragmented American Imagination', Mobilities 11 (2016).

${ }^{30}$ R. Dowling and C. Simpson, “'Shift - The Way you Move’: Reconstituting Automobility’, Continuum: Journal Media and Cultural Studies 27 (2013), D. Levinson, 'Climbing Mount Next: The Effects of Autonomous Vehicles on Society’, Minnesota Journal of Law, Science and Technology, 16 (2015).
} 


\section{The Contradiction of Technology Disrupting Law}

Barton Beebe observed that modern law and lawyers abhorred a vacuum. ${ }^{31}$ In his review of the Sputnik-era space law scholarship, he identified a profound anxiety that mid-twentieth century space travel had found, quite literally, a space that was without law. ${ }^{32}$ The solution was calls for more law - international treaties, registries of space launches, laws relating to liability, and space resource access schemes. ${ }^{33}$ Anxiety over a lack of law was confidently answered by calls for law. Although “disruption” did not feature in Sputnik-era space law scholarship, the current technology disrupting law frame dances the same two-step. The emphasis on disruption - on how emerging technological change renders existing laws out of date - waltzes directly to requirements for law reform.

This can be seen in the automated road vehicles disrupting law scholarship. The rhetorical questions produce a roadmap for reform. Traffic law needs to be amended to deem occupants of vehicles "drivers" 34 ; liability between occupants and manufacturers needs to be

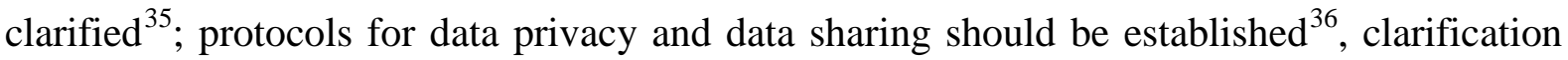
should be given whether intoxicated passengers in automated vehicles are driving under the

\footnotetext{
${ }^{31}$ B. Beebe, 'Law's Empire and the Final Frontier: Legalizing the Future in the Earlyorpus Juris Spatialis', Yale Law Journal 108 (1999).

32 Op. cit.

${ }^{33}$ See K. Tranter, 'The Law and Technology Enterprise: Uncovering the Template to Legal Scholarship on Technology', Law, Innovation and Technology 3 (2011), pp. 36-44.

${ }^{34}$ Brock, Don’t Need Drivers, Peck, Fatehi, Douma and Lari, SDVs Are Coming, pp. 869-70, Smith, Probably Legal.

35 Thomas, Programmers in the Driver's Seat, J. Levy, 'No Need to Reinvent the Wheel: Why Existing Liability Law Does Not Need to Be Preemptively Altered to Cope with the Debut of the Driverless Car', Journal of Business, Entrepreneurship and the Law 9 (2016), J.R. Zohn, 'When Robots Attack: How Should the Law Handle Self-Driving Cars That Cause Damages', University of Illinois Journal of Law, Technology and Policy (2015), p.484, F.P. Hubbard, 'Sophisticated Robots: Balancing Liability, Regulation, and Innovation', Florida Law Review 66 (2014), p.1858, S.H. Duffy and J.P. Hopkins, 'Sit, Stay, Drive: The Future of Autonomous Car Liability’, SMU Science and Technology Law Review 16 (2013).

${ }^{36}$ J. Schoonmaker, 'Proactive Privacy for a Driverless Age', Information and Communications Technology Law, 25 (2016).
} 
influence $^{37}$, and uniform national laws and standards should be established. ${ }^{38}$ Indeed, the disruption of automated vehicles creates the need for hyper-change to the specific rules that make up the law of the car.

Furthermore this change is to be ongoing. The pioneer period of automation requires specific regimes for trialing and testing. ${ }^{39}$ The transition from a human driven vehicle fleet to an automated fleet would require clarity of liability and responsibility between human and vehicles during the mixed fleet interregnum ${ }^{40}$; while a mature automated vehicle fleet might see the repeal of the driver licensing regimes. This seemingly establishes the disruption of automated road vehicles as requiring a cavalcade of legal change. ${ }^{41}$ The law will be in flux. There will be change. This is exactly what is captured by the phrase "technology disrupting law.” The certainty of the law of the car will be overtaken by attempts to catch-up with automated road vehicles. $^{42}$

However, notwithstanding disruption's underlying suggestion of crisis - that the substance of positive law needs to change - it is actually less dramatic than it seems. Indeed, positivism is nothing else but the theorization of substantive legal change. H.LA. Hart's concept of law was about identification of what was the legal system notwithstanding that substantive precepts change. ${ }^{43}$ Indeed, jurisdictions around the world can be seen as starting the reform process of changing law to accommodate automated vehicles. Reports have been

\footnotetext{
${ }^{37}$ Gurney, Unknown, pp. 419-423.

${ }^{38}$ Glancy, Autonomous and Automated and Connected, pp. 686-690, Swanson, Grab the Wheel, S.A. Beiker, 'Legal Aspects of Autonomous Driving', Santa Clara Law Review 52 (2012).

${ }^{39}$ W.J. Kohler and A. Colbert-Taylor, 'Current Law and Potential Legal Issues Pertaining to Automated, Autonomous and Connected Vehicles’, Santa Clara High Technology Law Journal 31 (2014), pp. 111-118.

${ }^{40}$ Surden and Williams, Technological Opacity, C. Schroll, 'Splitting the Bill: Creating a National Car Insurance Fund to Pay for Accidents in Autonomous Vehicles’, Northwestern University Law Review 109 (2015).

${ }^{41}$ Kohler and Colbert-Taylor, Current Law, p. 134; Peck, Fatehi, Douma and Lari, , SDVs Are Coming, p. 874.

42 On law catching up with technology see L. Bennett Moses, 'Recurring Dilemmas: The Law's Race to Keep

Up with Technological Change’, Journal of Law, Technology and Policy 7 (2007).

${ }^{43}$ H.L.A. Hart, The Concept of Law (Oxford, Clarendon Press, 1961).
} 
commissioned, recommendations made and legislation proposed or adopted. ${ }^{44}$ This seems less crisis and more the working of a positivist legal system with well-oiled "rules of change.” Rational identification of the greatest good in adapting law to automated vehicles is being translated into sensible legislative reform. That the word "driver" might disappear from the traffic law, or that manufacturers might be deemed liable for injury caused by automated vehicles, or that occupants in vehicles operating in autonomous mode, might be exempt from the current prohibition on holding personal electronic devices, will change the everyday of automobility, but law in its modern institutional form of legislation, of regulation, of registries, of executive and judicial decision-makers, of policing and prosecutions, seemingly endures. Automated road vehicle lawyers are as confident as their Sputnik-era ancestors, that law, as had been know, can regulate the new frontier.

In this it can be seen that the claim that technology is disrupting law is not as dramatic and crisis inducing as it sounds. Some of the substance of the existing law of the car needs to change, but modern law, the law of legislation, decision-makers, regulation and registries, continues. Whatever the challenges of disruptive technology, there is confidence that the tools and resources of modern law are up to the task of ensuring a non-disruptive future. ${ }^{45}$ Any disruption is due to the elites of policy-makers, legislators and their advisors failing to

\footnotetext{
${ }^{44}$ See Australia - National Transport Commission, Regulatory Barriers to More Automated Road and Rail Vehicles Issues Paper (February 2016) < https://www.ntc.gov.au/Media/Reports/(66E42530-B078-4B69-A5E353C22759F26E).pdf>, National Transport Commission, Regulatory Options for Automated Vehicles: Discussion Paper, (May 2016) < https://www.ntc.gov.au/Media/Reports/(049B1ED1-5761-44D5-9E3C814A9195285D).pdf>, National Transport Commission, Regulatory Reforms for Automated Road Vehicles: Policy Paper, National Transport Commission (November, 2016) https://www.ntc.gov.au/Media/Reports/(32685218-7895-0E7C-ECF6-551177684E27).pdf; National Transport Commission, National Guidelines for Automated Vehicle Trials Discussion Paper (November, 2016) < https://www.ntc.gov.au/Media/Reports/(FEAAC3B0-8F38-2C35-5FBC-4968034E6565).pdf>. EV - European Union, Parliamentary Debates, Declaration of Amsterdam on Cooperation in the Field of Connected and Automated Driving), https://english.eu2016.nl/documents/publications/2016/04/14/declaration-of-amsterdam. United States - United States Department of Transport and National Highway Traffic Safety Association, Federal Automated Vehicles Policy: Accelerating the Next Revolution In Roadway Safety, United States Department of Transport, National Highway Traffic Safety Association (2016). United Kingdom - Department for Transport UK, The Pathway to Driverless Cars: Summary Report and Action Plan, Department for Transport (2015).

${ }^{45}$ K. Tranter, 'Nomology, Ontology and Phenomenology of Law and Technology', Minnesota Journal of Law, Science and Technology 8 (2007).
} 
react or being captured by partisan perspectives. The joy of this perspective is that disruption point to a failure of the political will in not adequately using the machinery of modern law to ensure a smooth future, rather than with the machinery of modern law.

Which opens to the much more profound question regarding the machinery of modern law, whether it will endure so as to ensure the desirable smooth future? The disruption frame confidently suggests the forms and processes of modern law (forms and processes that emerged within a very specific material context) will continue into the future. This is the irony of the technology disrupting law frame. It sees disruption and legal change everywhere but in doing so affirms a vision of law as it has been known. The irony is that they might be right in a more basic sense; that the digital is disrupting law.

\section{The Actuality of Technology Disrupting Law}

Cornelia Vismann brought attention to law as a material practice. Her thesis was that what was considered law, legal practice and legal relations depends on the material forms and the technologies of organizing of those material forms. ${ }^{46}$ The movement from scroll to codex allowed the codification projects of the Roman jurists. ${ }^{47}$ Similar, printing, typing, mechanized copying and the technologies of file management, gave rise to modern law of designated decision-makers, registries and bureaucracy. It can be seen that the theorization of modern law is an intense mediation on how to do things with paper. Modern jurisprudence with its anxieties over interpretation, consistency, authority, discretion, is bound up with making a workable order that involves humans and paper. ${ }^{48}$ The law that is confidently

\footnotetext{
${ }^{46}$ C. Vismann, Files: Law and Media Technology (Stanford, Stanford University Press, 2008).

${ }^{47}$ Op. cit. $41-47$

${ }^{48}$ K. Tranter, ““Come a Day there Won’t be Room for Naughty Men Like Us to Slip About at All”: the MultiMedium Outlaws of Serenity and the Possibilities of Post-Literate Justice’, Law Text Culture 16 (2012).
} 
suggested can manage the disruption of technology is precisely this law. It is the law of legislation which crudely can be seen as the sovereign's written commands. It is the law of court decisions, where judges read past texts so as to craft a new text that determines rights and liabilities in a specific instance. ${ }^{49}$ It is the law of paper registries, where there is an actual, physical archive that allows hierarchical control over access. It is a law that serious theorists can analogize to a "chain novel”, where the soft technologies of humans reading and writing on paper are set out as the essence of law. ${ }^{50}$ The machinery of law that is supposed to prevent the disruption of technology is correctly a "paper machine.” 51

But as any lawyer concerned with technology disrupting law would superficially acknowledge these paper-based legal activities are in transition. The digital allows different engagements with information than the linearity of reading, writing and archiving paper. At one level the law has been cushioned by the impact of the digital. As Vismann notes there is a legacy effect when there is change in the material substrate of information in a reluctance to embrace the potential of the new media. ${ }^{52}$ In law computerization for the past 30 years has not changed the basic practice of law as an analogue human-centered activity of reading and writing. The digital, up until now, has sped up searches and allowed electronic versions of documents to be served and submitted. While paper might have increasingly been dispensed with, its forms, quite literally, still reigned supreme. There were just electronic versions of documents, forms and folders that still required human reading and decision-making. ${ }^{53}$ That this information was screened rather than printed was mostly immaterial. The digital was an aid to modern law and lawyering, increasing productivity, decreasing the physical

\footnotetext{
${ }^{49}$ B. Latour, The Making of Law: An Ethnography of the Conseil d'Etat (London, Polity, 2010).

${ }^{50}$ R. Dworkin, 'Law as Literature' in W.T.G. Mitchell, eds., The Politics of Interpretation (Chicago, University of Chicago Press, 1982).

51 J. Derrida, Paper Machine (Stanford, Stanford University Press, 2005).

${ }^{52}$ Vismann, Files, p.163.

${ }^{53}$ C. Vismann and M. Krajewski, ‘Computer Juridisms’, Grey Room 29 (2007).
} 
consumption of wood pulp and reducing the expenses incurred with managing the spatial physicality of paper.

However, the digital can do more than making it more convenient to find, write and make decision about documents. The hallmarks of the digital are speed, rigidity and automation. ${ }^{54}$ Algorithmic justice can organize data and make decisions differently to humans working paper apparatuses. This is not necessarily evident in legal AI research bots like ROSS or online dispute resolution services or, to continue the car theme, the contesting of parking fine apps. ${ }^{55}$ These applications organize and synthesize law, facts and precedents for human consideration and consumption. The human remains in the drivers-seat. There is automation of the intellectual menial tasks - identification of relevant authority, common facts and precedents and the piecing together of a first draft of a legal text - to make legal work cheaper and quicker. The challenge of the digital is with the programming of the human and its modern legal skills in reading, writing and analogue judgement, out of decisionmaking systems.

Lawrence Lessig, a long time ago, reassured that the digital would not be a lawless space. Rather the code will be law. ${ }^{56}$ There is a slight-of-hand going on within Lessig now familiar slogan. Code as law is not what lawyers writing about disruptive technologies see as law. His law must be juxtaposed with the early anarchical ideology of the Net as anything goes that he was attempting to distinguish. Lessig's code as law concerned order, structure and predictability, rather than modern law's commands of sovereigns and centralized, hierarchical decision-makers. His claim was that in the digital, code can be seen as doing some of the structural functions that modern law did in earlier eras.

\footnotetext{
${ }^{54}$ A. Pearson and K. Tranter, ‘Code, Nintendo’s Super Mario and Digital Legality’, International Journal for the Semiotics of Law 28 (2015), Tranter, Come a Day.

${ }^{55}$ B. Sheppard, 'Incomplete Innovation and the Premature Disruption of Legal Services', Michigan State Law Review (2015).

${ }^{56}$ L. Lessig, Code and Other Laws of Cyberspace (New York, Basic Books, 1999), L. Lessig, Code 2.0 (New York, Basic Books, 2006).
} 
But in doing so it does not have to recreate the institutions and practices of modern law. There are two examples. The first can be seen in the emergence of next-generation egovernment services. The Australian government recently reoriented the entire social security payments system as a smartphone based app. This facilitates through simply proto-literate taps and swipes on colorful icons, a direct data exchange between the welfare recipients and the government's servers. Further, this 24/7 data-flow of push-notifications and GPS enable surveillance was one stream feeding a swollen data river of information about the recipient and their relationships from banks, childcare centers, hospitals and other branches of government. This is then in real-time sampled and strained by algorithms that make immediate decisions about eligibility, payment amounts and debts. ${ }^{57}$ A minor character from the pantheon of modern law, the officious social welfare bureaucratic, making moralistic and prejudicial decisions about the deservingness of the poor ${ }^{58}$ seems to be disrupted by a system that gathers its own data and makes its own decisions without the need for humans and their petty prejudices. However, what also is disrupted is the essential constellation of modern law. The sovereign that commands, and gives and takes away now hides behind something that resembles a social media platform. The subject has the convenience of ease of engagement provided they submit to a regime of total surveillance. ${ }^{59}$

The second can be seen in the anti-law activity of some the disruptors in Christensen's sense in the development of automated road vehicles. Recently, both Uber and Otto have resisted some of the early automated vehicle law that required special approvals and licenses from traffic authorities for the trialing of self-driving vehicles on public roads. ${ }^{60}$ Replicating

\footnotetext{
${ }^{57}$ On the app and its consequences see L. Sleep and K. Tranter, 'The Visiocracy of the Social Security Mobile App in Australia', International Journal for the Semiotics of Law (2016) doi:10.1007/s11196-016-9498-1.

${ }^{58}$ L.E. White, 'Subordination, Rhetorical Survival Skills and Sunday Shoes: Notes on the Hearing of Mrs G' in M. Fineman and N.S. Thomadson, eds., At the Boundaries of Law: Feminism and Legal Theory (New York, Routledge, 1991).

${ }^{59}$ Sleep and Tranter, Visiocracy.

${ }^{60}$ M Harris, California's Fight with Uber's Self-Driving Car, Spectrum, IEEE, 2016 http://spectrum.ieee.org/cars-that-think/transportation/self-driving/californias-fight-with-ubers-selfdriving-car
} 
some of the brazen law-breaking of the share-economy apps, the strategy suggests the irrelevance of the institutions and practices of modern law to the digital. Notwithstanding, the confident claims of the automated road vehicle scholarship that law as it has been known can manage disruption, this disregard hints otherwise. The suggestion is that an automated vehicle networks needs not the state to function. It is very conceivable to envisage a swarm of automated vehicles being ordered, predictable and safe without road-rules, traffic police and road signage, whose standards and quality are ensured through consumer ratings and reviews, and disputes and liability being handed by instantaneous algorithmic justice. In the social security app example the state can be seen removing the human from the gathering of facts and the making of decisions. In the resistance of the automated vehicle disruptors to state control; what is being suggested is the removal not just of humans from decision making but the state as well.

As the materiality of information changes in the digital what is considered law will also change. ${ }^{61}$ This is something very different to the debates within first generation cyberlaw scholarship that Lessig was responding to. The suggestion is not an analogy to what David $\mathrm{R}$ Johnson and David Post argued regarding the uniqueness of the cyberspace with its lack of physical geography that required new forms of laws without borders. ${ }^{62}$ Indeed, as the 2000 s progressed it became increasing clear that those old border focused geographical Leviathans, the nation states, could, using the established tools of modern law regulate and police cyberspace, just as they regulated and policed outer-space four decades previously. ${ }^{63}$ Rather the suggestion is that the digital with its speed, rigidity and automation is transforming what law is - not just within what was known as cyberspace or on the road or in outer-space - but

\footnotetext{
${ }^{61}$ R. Brownsword, 'In the Year 2061: From Law to Technical Management', Law, Innovation and Technology 7 (2015).

62 D Johnson and D Post 'Law and Borders: The Rise of Law in Cyberspace', Stanford Law Review 48 (1996).

63 J Goldsmith 'Against Cyberanarchy', University of Chicago Law Review 65 (1998); J Goldsmith and T Wu, Who Controls the Internet?: Illusions of a Borderless World (New York, Oxford University Press, 2006).
} 
in its totality as a material practice. Vismann's point was that transformation of the materiality of information in early Imperial Rome from scroll to codex eventually facilitated transformations in how law was thought about and practiced through the codification of the Institutes. ${ }^{64}$ Changes to the materiality of information management led to new forms of law and legal practice. My suggestion is that the maturing of the digital represents a new epoch in the materiality of information which, with its speed, rigidity and automation, is disrupting the old paper and human machine of modern law.

It is the obscuring of this transformation by the disruption frame that is the problem for law and technology because it distracts from critical thinking about the form of law that is hardening in the digital. The speed, rigidity and automation of the digital means that once code, networks and algorithms are established, wholesale change is difficult. Redesigning modern law was in retrospect relatively easy; lawyers and decision makers were made aware of new precepts and expected to abide, with the threat of a malpractice suit or appeals to ensure compliance. The last 30 years of computerization has suggested that the digital involves archaeological strata of codes that become ossified and difficult to change. The familiar updates and patches of the digital tend to add further stratums, rather than deep change. What this means is there is critical work to be done in programming the basics of digital law before the networks solidify. Modern law became very experienced at identifying and managing the problems of a legal system comprising humans and paper and in doing so operationalized certain basic values - the rule of law which was concerned with fidelity to the text and individual rights as a counter balance to the excessive totality of sovereignty. What features of modern law, if any, should become encoded in the architecture of the digital is an essential issue for lawyers to grapple with in the present. Further it needs to be considered

\footnotetext{
${ }^{64}$ Vismann, Files, pp.61-70.
} 
whether the radical difference of the digital means an entire new ontology, one based on taking information seriously for example ${ }^{65}$, should be design principle.

What I am suggesting is that technology is disrupting law. However, by focusing on the obvious specifics and anxieties of a "disruptive technology”, lawyers are trapped in an anxious present that can only see the churning of the substantive precepts of existing laws. In this present the wider transformations from modern to digital law are obscured. While I am not disregarding the need for immediate reform in response to technological-driven change, the disruption frame's lack of a past and its cloudy future is a less than ideal for this pragmatic project. Rather there needs to be more integrated analysis that co-locates the specifics of immediate reform within the context of designing the digital future. Calling for modern law to cushion technological disruptions of the digital has role while the transition from paper to the digital is unfolding; but it must not obscure the more essential task of actively establishing the networks and protocols of the digital successor to modern law.

\section{Conclusion}

In summary the disruption frame offers a less than ideal matrix through which to think law and technology. The focus on a "disruptive technology" tends to result in analysis that has two limitations. The first is a narrowing of the temporal focus. Disruption establishes an anxious present that has no understanding of its past and a cloudy conception of its future. The second is that this presentism tends to result in a reaffirmation of the tools and techniques of modern law to manage disruption. Disruption sets up an urgent law reform agenda of fixing the law so as to catchup with the feared consequences of technological change.

\footnotetext{
${ }^{65}$ L. Floridi, The Ethics of Information (Oxford, Oxford University Press, 2013), L. Floridi, The Philosophy of Information (Oxford, Oxford University Press, 2011).In taking information seriously questions of storage and deletion become a priority. M.L. Jones, Ctrl+ Z: The Right to Be Forgotten (New York, New York University Press, 2016).
} 
However, this emphasis on fixing the substantive bits of the existing modern legal apparatus obscures more fundamental transformations at play. The digital is disrupting law, but not because cars are becoming self-driving robots rendering some provisions of the existing traffic rules ludicrous. Law as a material practice is a system of information management; and modern law at essence can be characterized as a material practice of information management that uses paper and humans. The digital with its features of speed, rigidity and automation fundamentally challenges - disrupts, even - the features and manifestations of modern law. The disruption frame is problematic for law and technology because it disguises the very real, and given the rigid ossification of code, the very urgent task, of determining what values, processes and structures should be built into the emerging architecture of digital law. 